\title{
sensors
}

ISSN 1424-8220

(C) 2008 by MDPI

www.mdpi.org/sensors

Full Paper

\section{Multi-instrumental Analysis of Tissues of Sunflower Plants Treated with Silver(I) Ions - Plants as Bioindicators of Environmental Pollution}

\author{
Sona Krizkova ${ }^{1}$, Pavel Ryant ${ }^{2}$, Olga Krystofova ${ }^{3}$, Vojtech Adam ${ }^{1,4}$, Michaela Galiova ${ }^{3}$, \\ Miroslava Beklova ${ }^{5}$, Petr Babula ${ }^{6}$, Jozef Kaiser ${ }^{7}$, Karel Novotny ${ }^{3}$, Jan Novotny ${ }^{7}$, Miroslav Liska \\ ${ }^{7}$, Radomir Malina ${ }^{7}$, Josef Zehnalek ${ }^{1}$, Jaromir Hubalek ${ }^{8}$, Ladislav Havel ${ }^{9}$ and Rene Kizek ${ }^{1, *}$ \\ 1 Department of Chemistry and Biochemistry, Mendel University of Agriculture and Forestry, \\ Zemedelska 1, CZ-613 00 Brno, Czech Republic \\ 2 Department of Agrochemistry, Soil Science, Microbiology and Plant Nutrition, Mendel \\ University of Agriculture and Forestry, Zemedelska 1, CZ-613 00 Brno, Czech Republic \\ 3 Department of Chemistry, Faculty of Science, Masaryk University, Kamenice 5, CZ-625 00 \\ Brno, Czech Republic \\ 4 Department of Animal Nutrition and Forage Production, Mendel University of Agriculture and \\ Forestry, Zemedelska 1, CZ-613 00 Brno, Czech Republic \\ 5 Department of Veterinary Ecology and Environmental Protection, Faculty of Veterinary Hygiene \\ and Ecology, University of Veterinary and Pharmaceutical Sciences, Palackeho 1-3, CZ-612 42 \\ Brno, Czech Republic \\ 6 Department of Natural Drugs, Faculty of Pharmacy, University of Veterinary and \\ Pharmaceutical Sciences, Palackeho 1-3, CZ-612 42 Brno, Czech Republic \\ 7 Institute of Physical Engineering, Faculty of Mechanical Engineering, Brno University of \\ Technology, Technicka 2896/2, CZ-616 69 Brno, Czech Republic \\ 8 Department of Microelectronics, Faculty of Electrical Engineering and Communication, Brno \\ University of Technology, Udolni 53, CZ-602 00 Brno, Czech Republic \\ 9 Department of Plant Biology, Faculty of Agronomy, Mendel University of Agriculture and \\ Forestry, Zemedelska 1, CZ-613 00 Brno, Czech Republic
}

* Author to whom correspondence should be addressed; e-mail:kizek@sci.muni.cz

Received: 26 December 2007 / Accepted: 15 January 2008 / Published: 24 January 2008

\begin{abstract}
The aim of this work is to investigate sunflower plants response on stress induced by silver(I) ions. The sunflower plants were exposed to silver(I) ions $(0,0.1,0.5$, and $1 \mathrm{mM}$ ) for $96 \mathrm{~h}$. Primarily we aimed our attention to observation of basic physiological parameters. We found that the treated plants embodied growth depression, coloured
\end{abstract}


changes and lack root hairs. Using of autofluorescence of anatomical structures, such as lignified cell walls, it was possible to determine the changes of important shoot and root structures, mainly vascular bungles and development of secondary thickening. The differences in vascular bundles organisation, parenchymatic pith development in the root centre and the reduction of phloem part of vascular bundles were well observable. Moreover with increasing silver(I) ions concentration the vitality of rhizodermal cells declined; rhizodermal cells early necrosed and were replaced by the cells of exodermis. Further we employed laser induced breakdown spectroscopy for determination of spatial distribution of silver(I) ions in tissues of the treated plants. The Ag is accumulated mainly in near-root part of the sample. Moreover basic biochemical indicators of environmental stress were investigated. The total content of proteins expressively decreased with increasing silver(I) ions dose and the time of the treatment. As we compare the results obtained by protein analysis - the total protein contents in shoot as well as root parts - we can assume on the transport of the proteins from the roots to shoots. This phenomenon can be related with the cascade of processes connecting with photosynthesis. The second biochemical parameter, which we investigated, was urease activity. If we compared the activity in treated plants with control, we found out that presence of silver(I) ions markedly enhanced the activity of urease at all applied doses of this toxic metal. Finally we studied the effect of silver(I) ions on activity of urease in in vitro conditions.

Keywords: Silver; Heavy metals; Plant biosensor; Sensors; Biochemical marker

\section{Introduction}

\subsection{Silver ions and their effects on organisms}

Due to many anthropogenic activities environment have been polluting by number of organic as well as inorganic compounds [1]. Therefore the concentration of these undesirable and in most cases highly toxic substances have enhanced [2]. The mechanism of their effects can be very heterogeneous. Because of these reasons the new procedures and technologies not only to monitor of levels of contamination but also to remediate the polluted environment have been still developing and suggesting. The ions of heavy metals and their compounds are considered as one of the most toxic substances polluting all parts of environment. Photographical industry, following electrochemistry and medicine are the main sources of one of the most toxic heavy metal ions, silver(I) ions. In water silver(I) can be found in many forms both as inorganic and organic compounds. Due to competing equilibria and kinetics in water hydrated silver ions, $\mathrm{Ag}^{+}$, may be also present in surface waters, which relates to the fact that $\mathrm{Ag}^{+}$has been shown to be highly toxic to aquatic life [3-5]. In the light of these facts the foundation called "The Silver Council", which was established in 1998, elaborated the basic characteristics of environmental norms for silver ions entering to environment from industry [6]. However the toxic effect of silver(I) ions on the organisms is still unclear. 
There have been suggested several mechanisms of silver ions effects on vitally important functions and processes. One of the most discussed is the interactions between $\mathrm{Ag}^{+}$and DNA, which have been studied by number of analytical methods (infrared and UV spectrometry, circular dichroism etc.) [7,8]. It was observed that silver ions bind rapidly on N7 guanine in dsDNA and, thus, interfere the replication processes [8].

It is generally known that prokaryotic as well as eukaryotic organisms intensively protect themselves against effects of heavy metals. The both groups of organisms have developed various strategies how they can detoxify xenobiotics. One of the common ones is synthesis of low molecular peptides and proteins rich in cysteine. In general plants synthesize peptides called phytochelatins $[9,10]$ and animals low molecular proteins called metallothioneins [11].

\subsection{Bio-indicators}

Numerous of plant and animal species can be used as bio-indicators of heavy metals pollution of the environment [12-19]. Aquatic animals, most of all various species of fishes, are very suitable for these purposes [20-22]. Nevertheless the question is how to asses the quality of the environment of interest through using of such living bio-indicators [23]. To assess the quality of the environment the investigations of the changes in behaviour, morphology, habitation or changes of basic morphometric properties (body weight, colour, length, etc.) are often used. All these data are only of qualitative character and are hardly to obtain due to requirements on large population of the target specie and the time period of the experiment. On the other hand, experiments using plants can be appropriate way how to substitute animal tests because no harming of animals and low demands on equipment.

\subsection{Silver ions analysis}

A determination of silver(I) ions in waters is difficult because the formation of a number of silver complexes with inorganic as well as organic compounds that however depress the acute silver toxicity $[6,24,25]$. The determination of silver ions is usually carried out by atomic absorption spectrometry $[26,27]$. To enhance the sensitivity of an analysis the pre-concentration of the silver ions in a sample is need. These processes prolong the total time of the analysis as well as enhance the cost of such experiment [27-29]. The electrochemical methods are alternative analytic techniques that make the silver ions determination possible in nM concentrations, mainly using carbon electrodes [30-36]. The modification of the surface of the carbon electrodes represents a unique tool for detection of heavy metal ions, peptides, proteins, nucleic acids and others [37-46].

The aim of this work is to investigate sunflower plants response on stress induced by silver(I) ions. For this purpose we employed multi-instrumental apparatus to detect and investigate total protein content, urease activity, spatial distribution of the heavy metal ions, and physiological and anatomical changes in the treated plants. 


\section{Material and Methods}

\subsection{Chemicals and $\mathrm{pH}$ measurements}

Urease EC 3.5.1.5 (Jack Beans, type III; $45000 \mathrm{IU} / \mathrm{g}$ ) was purchased from Sigma Aldrich (St. Louis, USA). Acetic acid was purchased from Fluka (USA). All other reagents used were purchased from Sigma Aldrich in ACS purity unless noted otherwise. Stock standard solutions were prepared by ACS water (Sigma-Aldrich, USA) and stored in the dark at temperature of $-20{ }^{\circ} \mathrm{C}$. Working standard solutions were prepared daily by dilution of the stock solutions. All solutions were filtered through a $0.45 \mu \mathrm{m}$ Nylon filter discs (Millipore, Billerica, Mass., USA) prior to HPLC analysis. The $\mathrm{pH}$ value was measured using WTW inoLab Level 3 with terminal Level 3 (Weilheim, Germany), controlled by the personal computer program (MultiLab Pilot; Weilheim, Germany). The pH-electrode (SenTix-H, pH $0-14 / 3 \mathrm{M} \mathrm{KCl}$ ) was regularly calibrated by set of WTW buffers (Weilheim, Germany).

\subsection{Plants, cultivation conditions and a sample preparation}

Sunflower plants (Helianthus annuus L.) were used in our experiments. The sunflower seeds were germinated on wet filter paper in special vessels at $25 \pm 2{ }^{\circ} \mathrm{C}$ in dark (box Chirana, Czech Republic). After 10 days, the sunflower seedlings were placed into vessels containing tap water and cultivated in Versatile Environmental Test Chamber (MLR-350 H, Sanyo, Japan) for eight days with 14 hours long daylight per day (maximal light intensity was about $100 \mu \mathrm{E} \cdot \mathrm{m}^{-2} \mathrm{~s}^{-1}$ ) at a temperature $22{ }^{\circ} \mathrm{C}$ and humidity $65 \%$. Further $\mathrm{AgNO}_{3}$ was added to the cultivation solution at final concentrations of 0 (control sample), 0.1, 0.5 and $1 \mathrm{mM}$. The sunflower plants placed in the vessels that contained tap water with addition of silver(I) ions were treated for five days. Seven plants from each experimental group were harvested at certain time intervals during the experiment, and their roots were rinsed three times in distilled water and 0.5 M EDTA. Prior to their analysis each harvested plant was divided into leaves, stem and root.

\subsection{Laser spectrometry}

The LIBS experimental setup used is shown in Fig. 1. The second harmonic (532 nm) of the Nd:YAG laser system (Brilliant B, Quantel, France) was used to create the LIBS micro-plasma by focusing the laser beam with a $16 \mathrm{~mm}$ focal-length glass doublet (Sill Optics, Germany). The laser pulse width was $\sim 5 \mathrm{~ns}$ and beam diameter $8 \mathrm{~mm}$. The energy of the laser pulse ( $\sim 10 \mathrm{~mJ}$ at the sample) was set and controlled by an energy meter (Field Master LM-P10, Coherent, USA).

The sample was placed to the sample holder inside the ablation chamber (Tescan, Czech Republic) to the stage with precision movements $(2 \mu \mathrm{m}$ in $\mathrm{x}, \mathrm{y}$ and $\mathrm{z}$ direction). The LIBS analysis was performed in air on atmospheric pressure. The ablation spot was targeted and controlled for each shot by a CCD camera placed outside of the chamber. For the temporally and spectrally resolved analysis the LIBS plasma radiation was collected with quartz objectives and transported by a $3 \mathrm{~m}$ fiber optic system onto the entrance slit of the $0.32 \mathrm{~m}$ monochromator (TRIAX 320, Jobin Yvon, France). In this study, the grating $2400 \mathrm{~g} / \mathrm{mm}$ of the monochromator and $50 \mu \mathrm{m}$ entrance slit were used. As a detector 
an ICCD camera (Horiba, Jobin Yvon, France) was employed. The camera was triggered by the Q-switch signal of the laser.

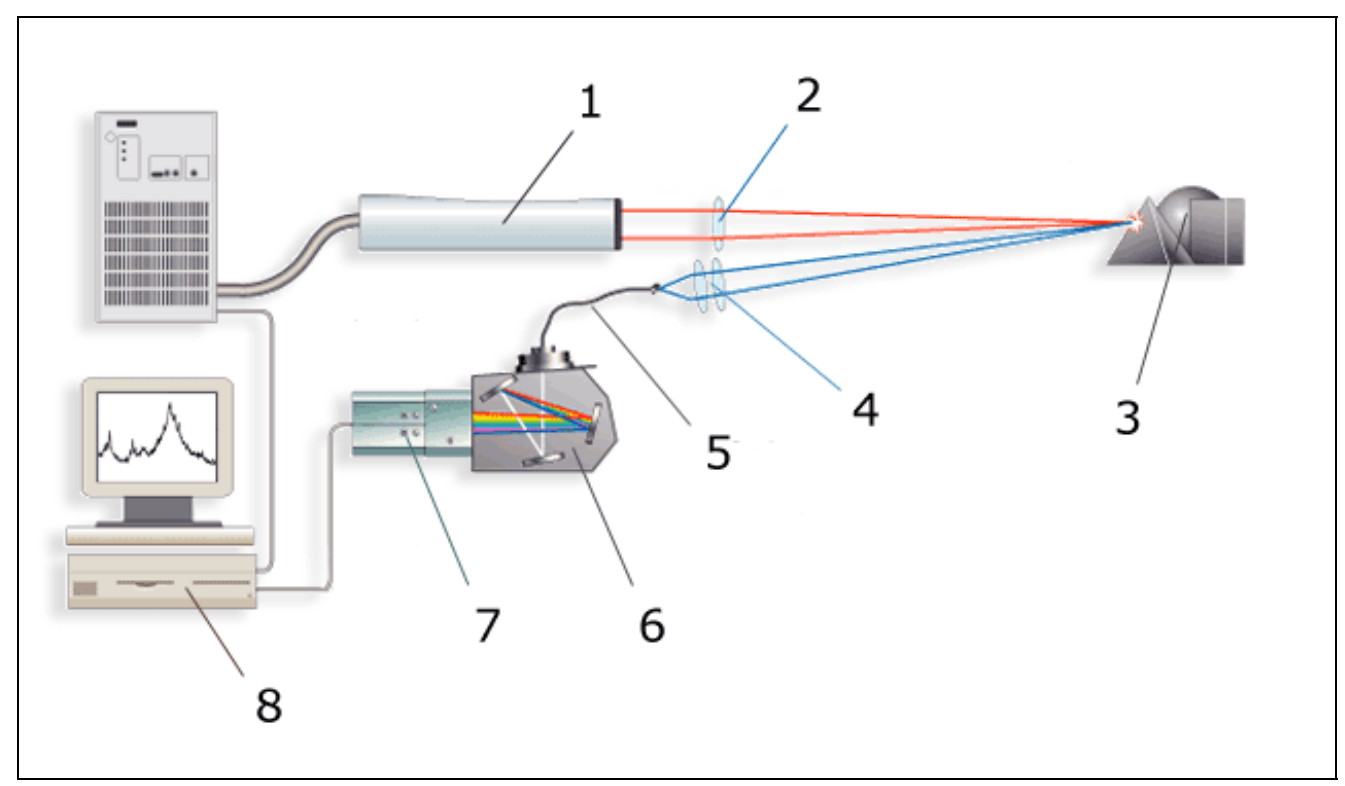

Figure 1. The LIBS experimental setup. 1 - Nd:YAG ablation laser, 2 - focusing optics, 3 - the analyzed sample, 4 - collecting optics, 5 - optical fiber, 6 - monochromator, 7 - ICCD camera, 8 - personal computer.

\subsection{Automated spectrometric measurements}

Spectrometric measurements were carried using an automated chemical analyser BS-200 (Mindray, China). Reagents and samples were placed on cooled sample holder $\left(4{ }^{\circ} \mathrm{C}\right)$ and automatically pipetted directly into plastic cuvettes. Incubation proceeded at $37^{\circ} \mathrm{C}$. Mixture was consequently stirred. The washing steps by distilled water $(18 \mathrm{~m} \Omega)$ were done in the midst of the pipetting. Apparatus was operated using software BS-200 (Mindray, China).

\subsubsection{Urease activity determination - An indophenol assay (Berthelot method)}

Plant tissues samples (approximately 2 grams) were homogenized in mortar for five minutes. Then twenty millilitres of $30 \%$ ethanol was added and this solution was poured into a bottle $(50 \mathrm{ml})$ and vortexed at $300 \mathrm{rpm}, 8{ }^{\circ} \mathrm{C}$ for 30 minutes using vortex (GFL, Germany). The extract was centrifuged for $10 \mathrm{~min}$ at $5000 \mathrm{~g}$ (Hettich, Geramy) and then the supernatant was collected. The supernatant (10 $\mu 1)$ was mixed with $448 \mu \mathrm{l}$ of hypochlorite solution $\left(12 \% \mathrm{NaOCl}, 0.4 \mathrm{M} \mathrm{Na}_{2} \mathrm{HPO}_{4}\right.$ and $0.37 \mathrm{M} \mathrm{NaOH}$, adjusted to $\mathrm{pH} 12$ ) and with $42 \mu 1$ of phenol solution (sodium nitroprusside, $7 \%$ phenol). This mixture was stirred and incubated for $15 \mathrm{~min}$ at $37^{\circ} \mathrm{C}$. After this incubation the differences of absorption at 630 and $670 \mathrm{~nm}$ were measured. 


\subsubsection{Protein determination - Biuret test}

Weighed plant tissues (approximately $0.2 \mathrm{~g}$ ) were transferred to a test-tube. Then, liquid nitrogen was added to the test-tube, and the samples were frozen to disrupt the cells. The frozen sample was transferred to mortar and spread for $1 \mathrm{~min}$. Then exactly $1,000 \mu \mathrm{l}$ of $0.2 \mathrm{M}$ phosphate buffer ( $\mathrm{pH} 7.2)$ was added to mortar, and the sample was spread for $5 \mathrm{~min}$. The homogenate was transferred to a new test-tube. The frozen samples were homogenised by shaking on a Vortex-2 Genie for 5 min at $4{ }^{\circ} \mathrm{C}$ (Scientific Industries, USA) and sonicated using a Bandelin Sonopuls HD 2070 for $10 \mathrm{~s}$ at $7 \mathrm{~W}$ (Germany). The homogenate was centrifuged $(14000 \times \mathrm{g})$ for $15 \mathrm{~min}$ at $4^{\circ} \mathrm{C}$ using a Universal $32 \mathrm{R}$ centrifuge (Hettich-Zentrifugen, Germany). The supernatant was filtered through a $0.45 \mu \mathrm{m}$ Nylon filter discs (Millipore, Billerica, Mass., USA) prior to analysis.

For determination of the total protein content the biuret solution $(15 \mathrm{mM}$ potassium sodium tartrate, $100 \mathrm{mM} \mathrm{NaI}, 15 \mathrm{mM} \mathrm{KI}$ and $5 \mathrm{mM} \mathrm{CuSO}_{4}$ ). As a standard albumin ( $1 \mathrm{mg}$ in $1 \mathrm{ml}$ of phosphate buffer, $\mathrm{pH} 7$ ) was used. The measurement was done as follows: $180 \mu 1$ of the biuret solution was mixed with $45 \mu 1$ of real or standard sample; after stirring and incubating $\left(10 \mathrm{~min}\right.$. at $\left.37^{\circ} \mathrm{C}\right)$ the absorbance at 546 nm was measured.

\subsection{Anatomical analysis of plant samples}

The observations were performed with fresh stem sections of plants. Lignified cell walls were visualized by ultraviolet (UV) excitation without additional fluorescent staining. At each experimental group of plants 25 - 30 sections were evaluated. All observations were performed on fluorescent microscope (Olympus AX 70) equipped with broad spectrum UV excitation.

\subsection{Statistical analysis}

Data were processed using MICROSOFT EXCEL $\AA$ (USA) and analyzed by the QCExpert software (TriloBite, Statistical Software, Czech Republic) using analysis of variance (ANOVA). Results are expressed as mean \pm S.D. unless noted otherwise. Statistical significance of the differences between weight and area of clusters was determined. Differences with $\mathrm{p}<0.05$ were considered significant.

\section{Results and Discussion}

In the case of silver ions toxicity the attention is devoted to aquatic organisms [1,47-53], mainly to fishes due to extremely low lethal doses, which vary from units to ten of micrograms per litre $[3,4,48$ 56]. On the other hand it is little known about the influence of silver ions on plants. It is well known that a presence of a toxic metal in a plant cell results in synthesis of stress plant peptides and proteins. These biologically active molecules can be used for evaluation of chronic as well as acute toxicity of a toxic metal or as biomarkers of assessment of environmental pollution (Fig. 2).

\subsection{Physiological changes in sunflower plants exposed to silver(I) ions}

To investigate influence of silver(I) ions on plant we selected sunflower plants (Helianthus annuus L., Asteraceae, syn. Compositae). The sunflower plants were exposed to silver(I) ions $(0,0.1,0.5$, and 1 
$\mathrm{mM}$ ) for $96 \mathrm{~h}$. The images of the plants in time scale of the treatment are shown in Fig. 3. It clearly follows from the figures that the plants exposed to silver(I) ions embody growth depression; only control set of the plants demonstrates leaves growth. The root system of the plants exposed to silver(I) ions shows also physiological changes compared to control plants. Particularly we observed growth depression and coloured changes that indicate the entry of silver ions to the plants. Moreover the sunflower plants treated with silver(I) ions lack root hairs (Fig.3).

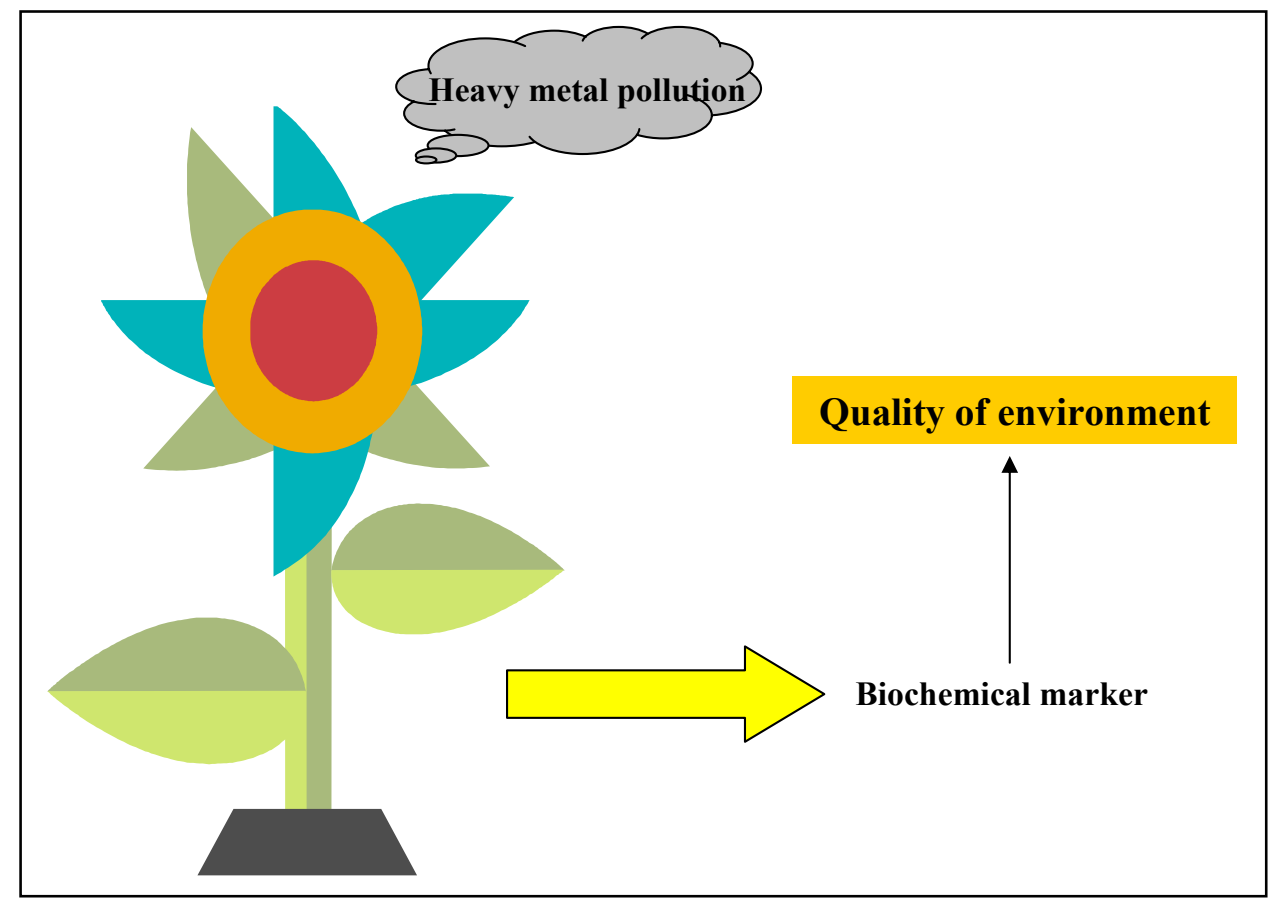

Figure 2. The scheme of environment quality assessment based on determination of biochemical markers presented in plants.

\subsection{Changes in the treated plants fresh weight}

At the end of each experimental day the part of the plants were harvested and weighed. Based on these results the growth curves were determined (Fig. 4). The control plants demonstrated moderate loss of fresh weight (Fig. 4 whole plant) because of their cultivation in distilled water without macroand microelements supplement. This effect is mostly observable at shoots; root systems were more stimulated (Fig. 4). The influence of silver(I) ions on sunflower plants growth parameters was well evident. Rate of loss of plants fresh weight enhanced with the increasing silver(I) ions doses and with the time of the exposure. This effect was more evident at the shoot parts of the plants (hypocotyls, stems) in comparison with the root system. The decrease in the fresh weight is probably connected with an increase in a metabolic activity of the plants exposed to silver(I) ions due to very limited supply of inorganic as well as organic compounds needed for plant development. In addition we found that the content of chlorophylls (chlorophyll $a$ and chlorophyll $b$ ) was lower in the plants treated with silver(I) ions compared to the control group of the plants. This indicates the damage of photosynthetic processes and the decrease of the total energetic metabolism of the plants treated with silver(I) ions. 


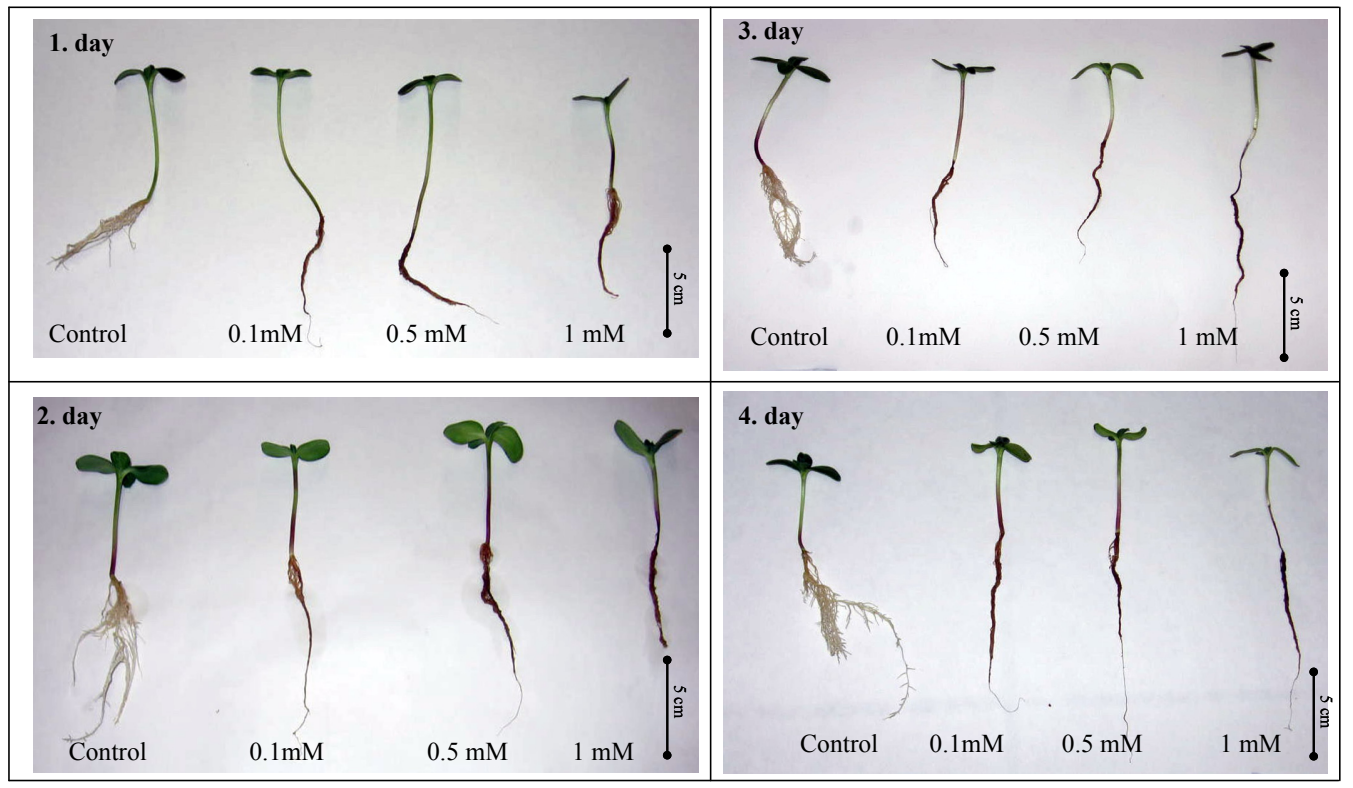

Figure 3. Images of the sunflower plants during $96 \mathrm{~h}$ treatment with silver(I) ions.

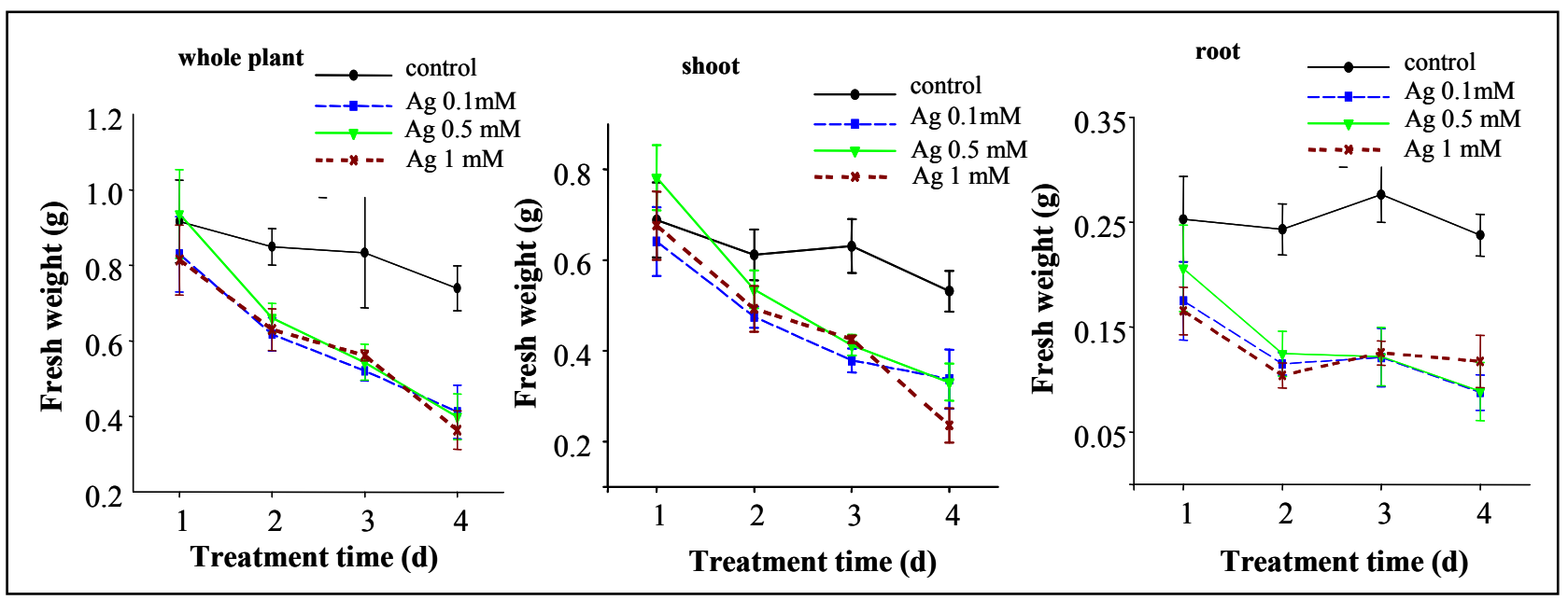

Figure 4. Fresh weight changes (whole plant, shoot and root) of sunflower plants exposed to various doses of silver(I) ions for $96 \mathrm{~h}$.

\subsection{Anatomical changes of sunflower shoots (hypocotyls, stems) and roots}

Using of autofluorescence of anatomical structures, such as lignified cell walls, it was possible to determine the changes of important shoot and root structures, mainly vascular bungles and development of secondary thickening. The differences in vascular bundles organisation, parenchymatic pith development in the root centre and the reduction of phloem part of vascular bundles are well observable (Fig. 5). The most important changes in hypocotyls anatomy were as follows: the increased robustness of cuticle, increase of lignification and suberinization of the cell walls of epidermis and 
outer cortex, and changes in new vascular bundles differentiation with increasing silver(I) ions dose. These hallmarks can be related to changes of water transport caused by silver(I) ions.

Very evident and characteristic changes were determined in root structure. With increasing silver(I) ions concentration the vitality of rhizodermal cells declined; rhizodermal cells early necrosed and were replaced by the cells of exodermis. Changes were well evident in the structure of stele, mainly in pith development. Deposition of silver in the pitch cell walls as well as in inner xylem parts was expressively evident in connection with increasing silver(I) ions concentration.

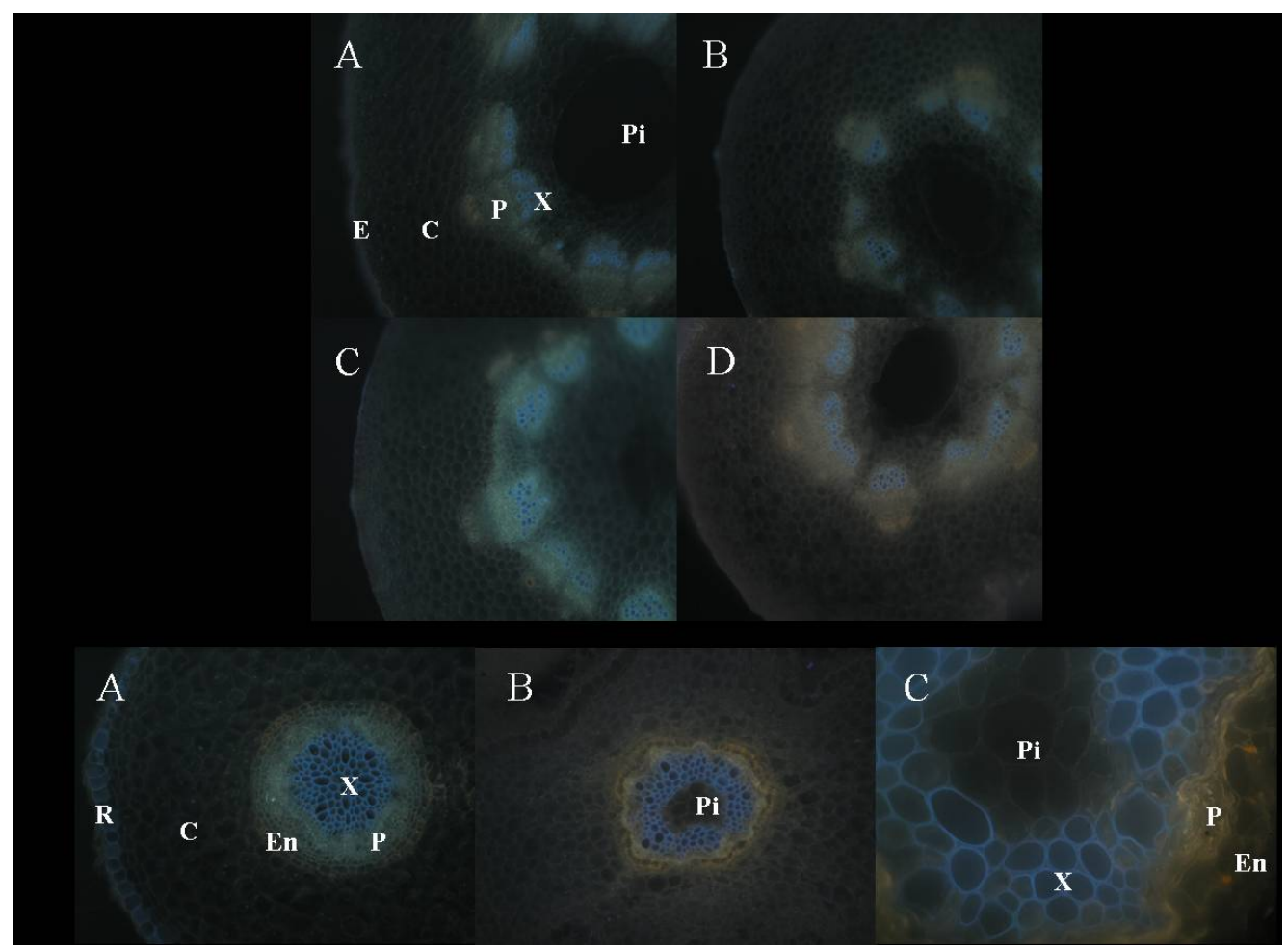

Figure 5. Sunflower shoot. Transverse stem section of sunflower cultivated without (A) and treated with silver(I) ions $-0.1 \mathrm{mM}(\mathbf{B}), 0.5 \mathrm{mM}(\mathbf{C})$ and $1.0 \mathrm{mM}(\mathbf{D})$ at fourth day of the treatment. Blue fluorescence - lignified cell walls. E - epidermis, C - cortex, P phloem, X - xylem, Pi - pith. Sunflower root. Transverse root section of sunflower cultivated without $(\mathbf{A})$ and treated with silver(I) ions $-0.1 \mathrm{mM}(\mathbf{B})$, with detail $(\mathbf{C})$ at fourth day of the treatment. Magnification $\times 100$.

\subsection{Spatial distribution of silver(I) ions in the plant tissues}

Laser Induced Breakdown Spectroscopy (LIBS) is a simple spectrochemical sensor technology. LIBS utilises the emission of a high-temperature microplasma created by focusing a laser beam to the surface of the investigated sample. The spectrum of light emission is collected by a detector and its intensity at specific wavelengths is recorded [57]. The method allows real-time multi-element analysis in-situ and even remotely. The advantages of this method, i.e. usually none or very simple sample preparation, together with the capability of analysis with high spatial resolution [58] make it possible to utilize it in a wide-range of applications [57,58]. Basically, the achievable spatial resolution of LIBS 
is determined by the size of the laser craters produced within the material [57]. However, LIBS as a technique for simultaneous multi-elemental analysis is dating from the 1980s [59,60], as an emerging chemical sensor has picked up considerably during the past decade [57]. Recently, the LIBS was exploit among other for monitoring of accumulation of selected chemical elements in different structures of plant species [61-63].

The single-shot LIBS analysis was performed along the $\sim 25 \mathrm{~mm}$ long Helianthus annuus L. stem sections. The LIBS's ICCD detector was gated $1 \mu$ s after the Q-switch signal and the observation window was $10 \mu \mathrm{s}$. Typical LIBS spectrum is shown in Fig. 6aA), together with a photograph of LIBS ablation craters (Fig. 6B). For $\mathrm{Ag}$ and $\mathrm{Cu}$ detection the $328.07 \mathrm{~nm} \mathrm{Ag}(\mathrm{I})$ and $324.75 \mathrm{~nm} \mathrm{Cu}(\mathrm{I})$ lines were used, respectively. For the mapping the background was subtracted (for each shot) and the area under the selected peak (for appropriate chemical element) was calculated.

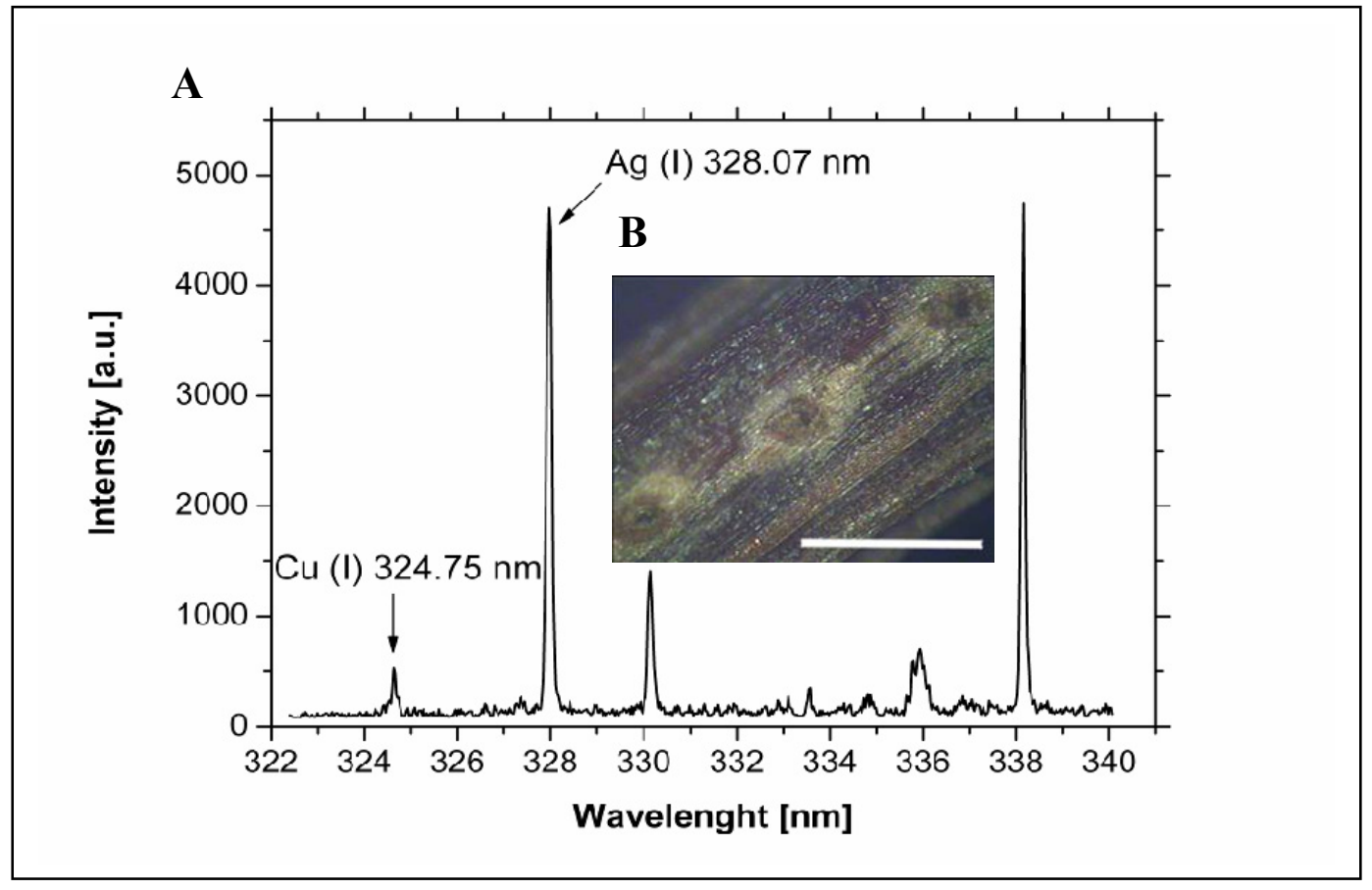

Figure 6. The typical LIBS spectrum with the $328.07 \mathrm{~nm} \mathrm{Ag(I)}$ and $324.75 \mathrm{~nm} \mathrm{Cu(I)} \mathrm{lines}$ used in the analysis (A) together with the image of three ablation craters (B). The bar on $\mathbf{B}$ has a length of $500 \mu \mathrm{m}$.

Figure 6 demonstrates the capability of LIBS to signalize the trends in accumulation of different elements in selected structures of the sample. To trace the uptake of $\mathrm{Ag}$ and $\mathrm{Cu}$ in the investigated area of the leaf samples, a statistical analysis was carried out on the intensity data set from each sample. Because the measured intensity values had a log-normal distribution the average of the logarithm of intensity values was calculated [64]. From these data we found that in the leaves of the plants the overall $\mathrm{Cu}$ content follows the changes in the $\mathrm{Ag}$ content.

The distribution of $\mathrm{Cu}$ and $\mathrm{Ag}$ along the stem sections for different days of treatment is shown in Figs. 7 and 8. The LIBS analysis was finished on the closer part of stem towards the root system (position $\sim 25 \mathrm{~mm}$ on the sample). These graphs clearly demonstrate the advantage of the spatiallyresolved LIBS analysis. While the overall content of the $\mathrm{Ag}$ and $\mathrm{Cu}$ follows each other (Fig. 7), the 
spatial distribution of these elements is different. The Ag is accumulated mainly in near-root part of the sample (Fig. 8A), on contrary the $\mathrm{Cu}$ is spread more uniformly within the stem (Fig. 8B).

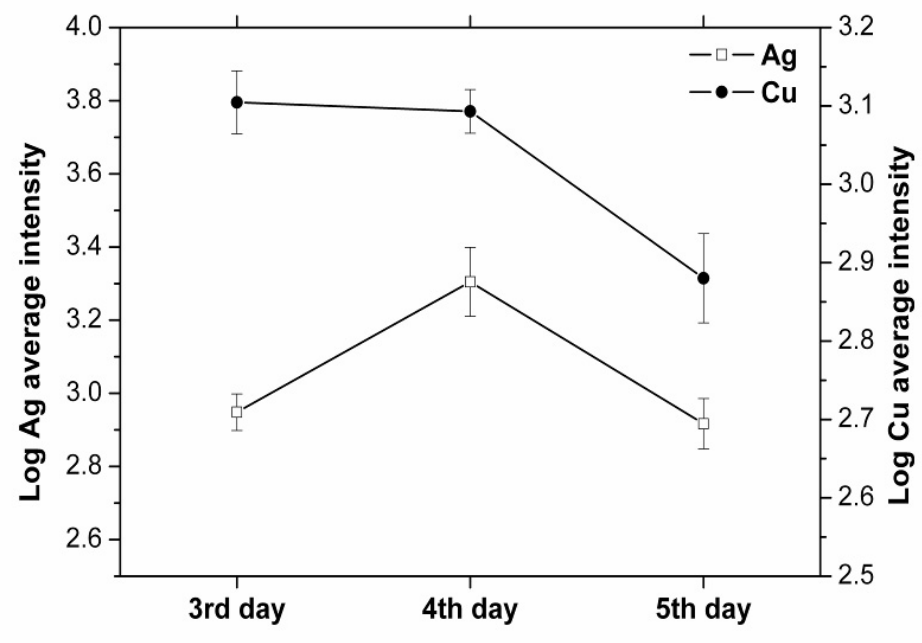

Figure 7. The average intensities calculated from logarithm of intensity data obtained from LIBS analyses.

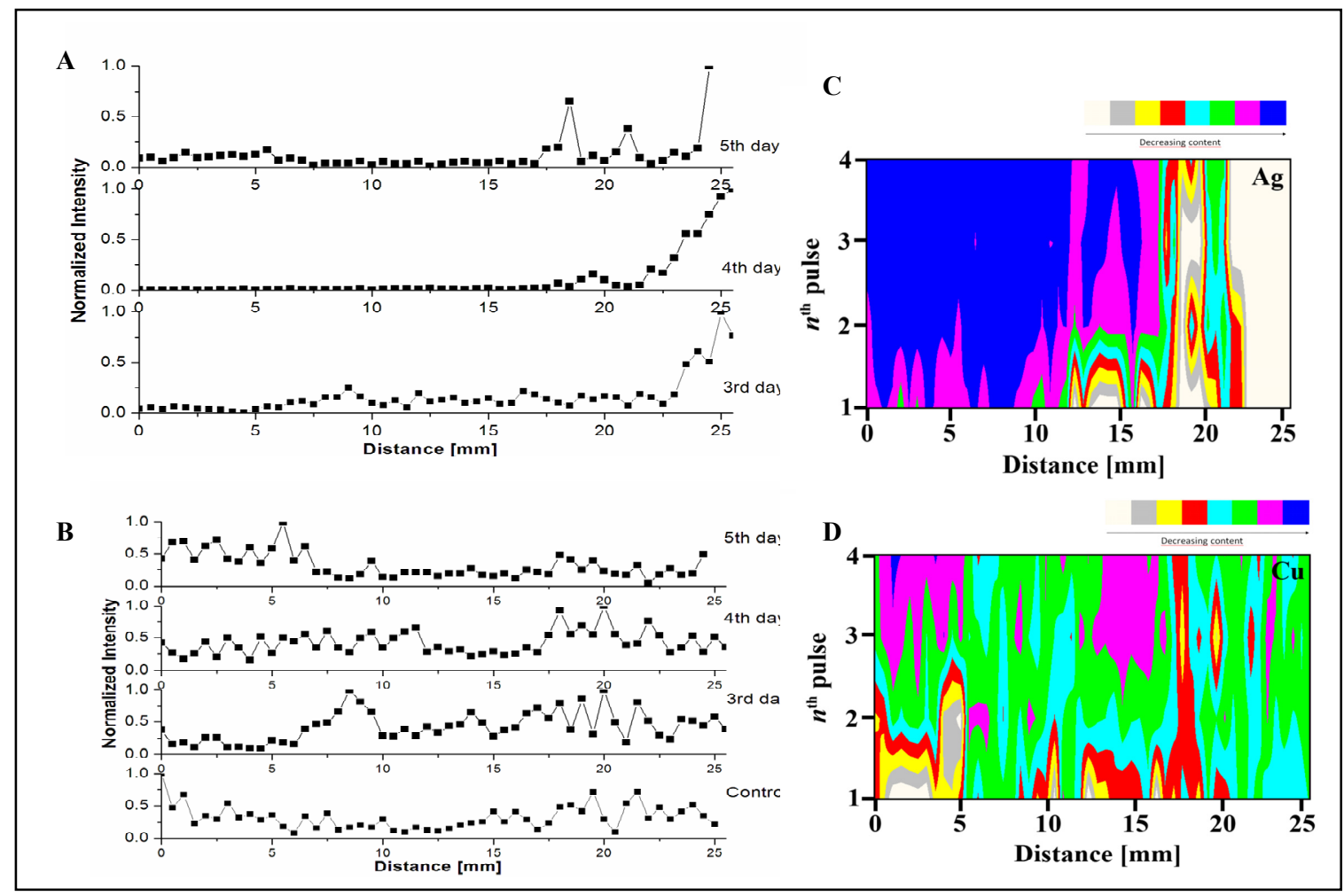

Figure 8. Accumulation of silver (A) and copper (B) along the investigated stem samples. Maps of the accumulated silver (C) and copper (D) measured by the LIBS technique for quasy $3 \mathrm{D}$ analyses of the stem sample of interest. 
The possibility to utilize LIBS for 3D analysis of element distribution within the sample is examined in Fig. 8C,D. The different layers were monitored with four subsequent laser pulses. We should note that in spite to the fact that on the frame of this exploratory study the depth of ablation craters was not measured, the different distribution of elements within the analyzed layers is clearly observable. On the ongoing work an upgrade of the instrumental device for simultaneous LIBS - laser ablation inductively coupled plasma mass spectrometry (LA-ICP-MS) is planned. Utilizing such an apparatus, also the calibration for the main components will be possible, using selected calibration standards and measuring the depth of the ablation-craters.3.5 Biochemical indicators of environmental stress.

\subsubsection{The total protein content}

At the plants treated with silver(I) ions the changes were observable also in total content of proteins determined using biuret reaction. For this purpose automatic analyzer BS-200 was used. The calibration curve obtained (albumin was selected as standard) was strictly linear within the range from 1 to $1000 \mathrm{mg} / \mathrm{ml}$ (Fig. 9A). The level of water soluble proteins was markedly lower in root system, where also the difference between control plants and plants treated with silver(I) ions was mostly distinctive. In addition the total content of proteins expressively decreased with increasing silver(I) ions dose and the time of the treatment (Fig. 9B). Shoots of sunflower plants demonstrated less distinct proteins content in plants treated with silver(I) ions in comparison with root system (Fig. 9C). As we compare the results obtained by protein analysis - the total protein contents in shoot as well as root parts - we can assume on the transport of the proteins from the roots to shoots. This phenomenon can be related with the cascade of processes connecting with photosynthesis.

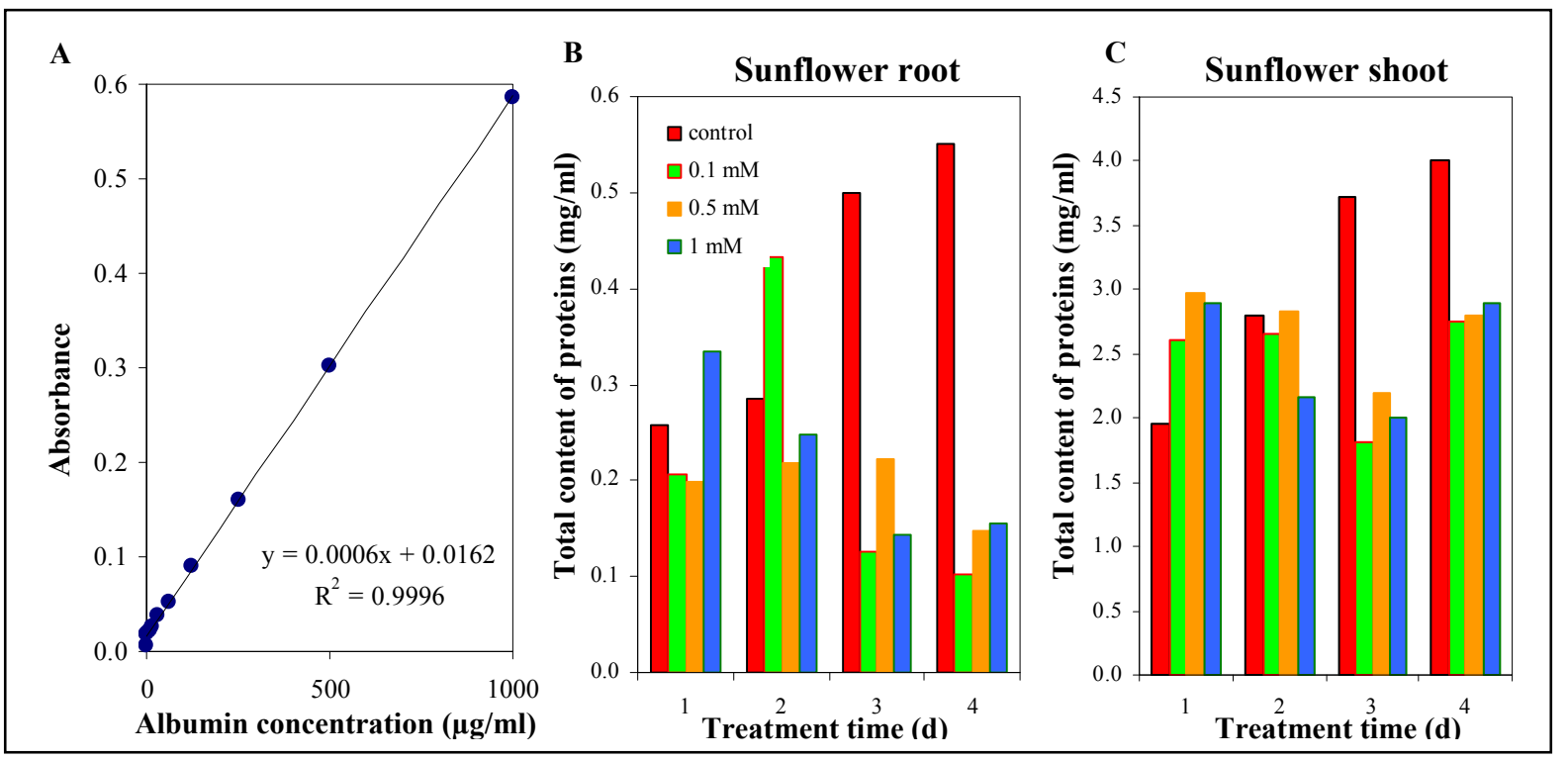

Figure 9. Total content of proteins soluble in water determined spectrometrically using biuret reaction. The dependence of signal height on albumin concentration (A). Total content of proteins in root $(\mathbf{B})$ and shoots $(\mathbf{C})$ of sunflower plants exposed to silver(I) ions. 


\subsubsection{Urease activity}

One of the crucial plant enzymes, which are extremely sensitive to presence of heavy metals ions, is urease. Due to this feature the number of different biosensors to detect heavy metals was proposed $[65,66]$. All experiments appear from enzymes that are very carefully purified. However investigation of enzyme activities for environment pollution assessment is also interesting. Sunflower plants demonstrate measurable level of urease activity. Because of this fact we aimed on the monitoring of urease activity. For our purposes the methodology enabling urease activity determination using automated detection was optimised. Automated spectrophotometric analysator BS-200 was used. The principle of this method is based on the fact that urease decomposes carbamide into ammonia that is subsequently detectable as coloured product $[65,67]$. The strictly linear calibration curve is shown in Fig. 10A. Relative standard deviation was about $1.5 \%$ and the analysis of 40 samples was realized within $30 \mathrm{~min}$. For the examination of the activity of enzyme urease under our experimental conditions enzyme kinetic was observed. The measurements resulted in Michaelis-Menten constant $\mathrm{Km} 3.8 \mu \mathrm{M}$ (Fig. 10B).

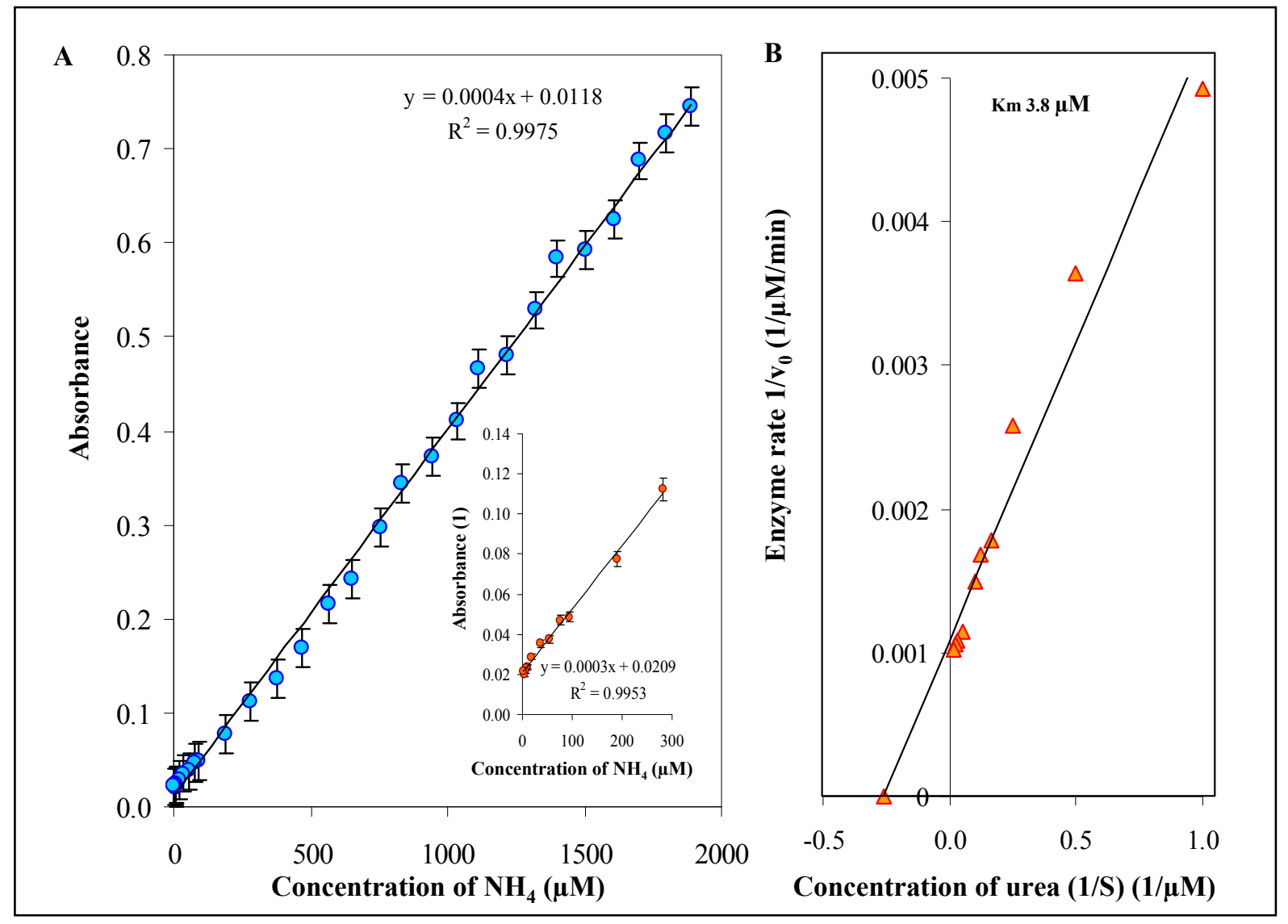

Figure 10. Spectrometric automated analysis of urease activity. The dependence of total amount of released ammonia on height of the obtained signal (A). Enzyme kinetic of soybean urease (B). 
A

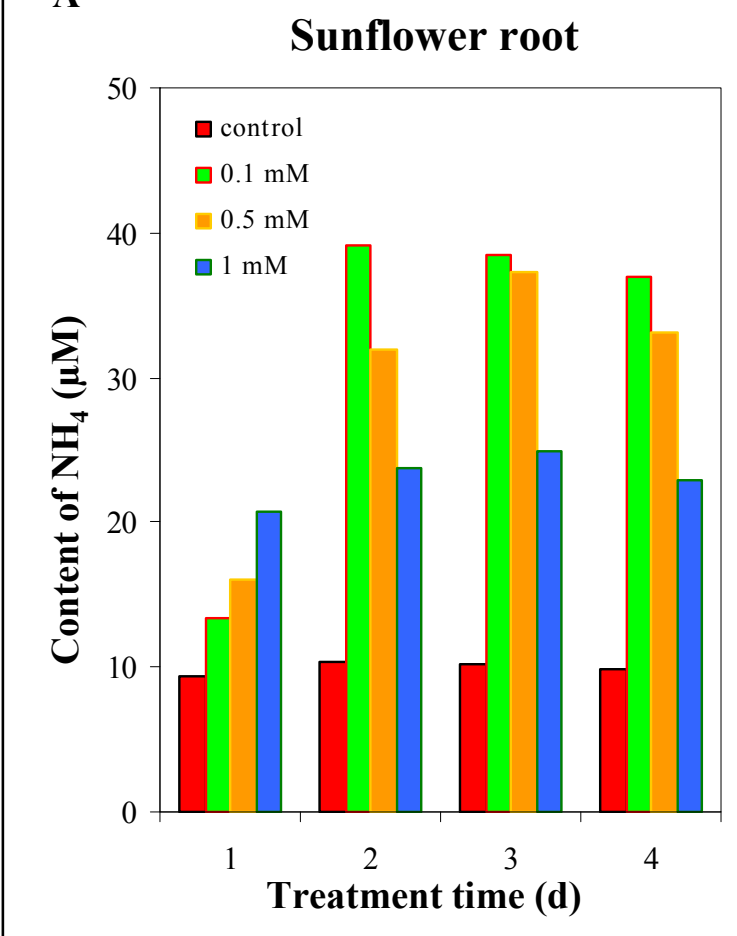

B

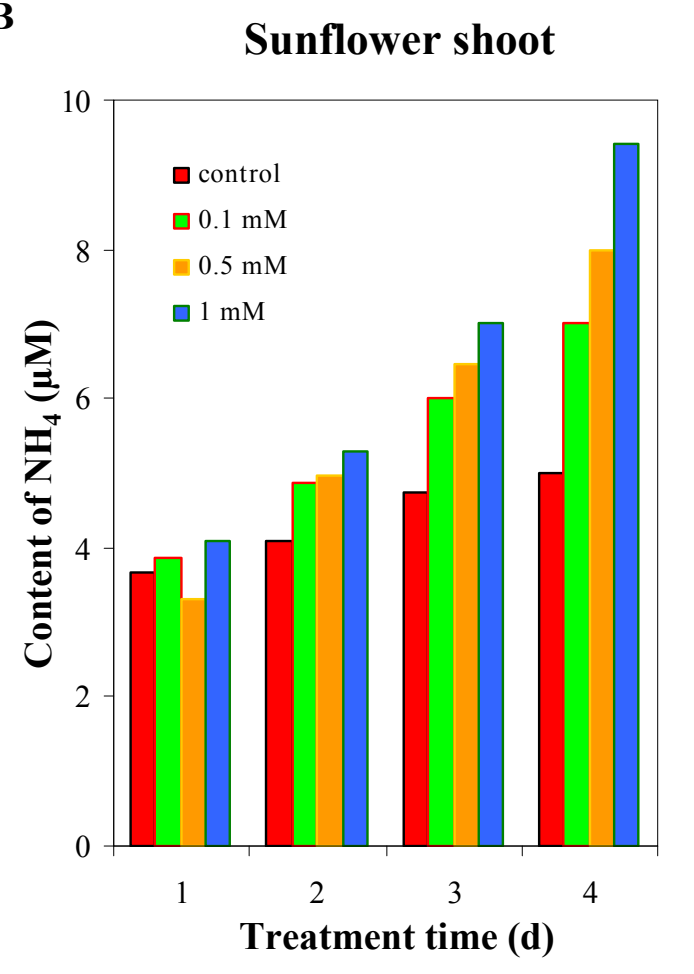

Figure 11. The changes in urease activity in sunflower plants exposed to silver(I) ions, roots (A) and shoots (B).

Sunflower plants demonstrated higher urease activity in root system in comparison with shoots (Fig. 11A,B). The activity in roots was app. five times higher compared to shoots. If we compared the activity in treated plants with control, we found out that presence of silver(I) ions markedly enhanced the activity of urease at all applied doses of this toxic metal.

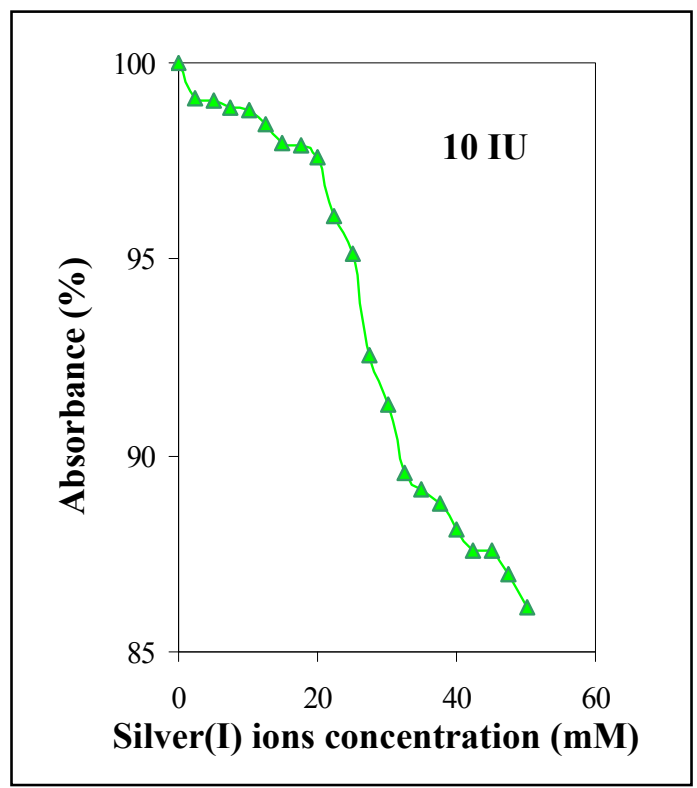

Figure 12. The changes of activity of commercially available urease in the presence of silver(I) ions. 


\subsection{The changes of urease activity in the presence of silver(I) ions}

In addition we were interested in the issue how can the presence of silver(I) ions influence the activity of purified urease. Into the solution of urea $(1 \mathrm{mM})$ silver(I) ions at final concentrations $0 ; 5$; $10 ; 15 ; 20 ; 25 ; 30 ; 35 ; 40 ; 60 ; 80$ and/or $100 \mu \mathrm{M}$ were added. To this solution urease (10 IU) was added and mixture was incubated for $60 \mathrm{~s}$ at $37{ }^{\circ} \mathrm{C}$ under shaking (300 rpm). The samples were analysed using procedure described above. Urease activity was inhibited by silver(I) ions; concentrations higher than $20 \mathrm{mM}$ quickly led to reduction in urease activity (Fig. 12).

\section{Conclusion}

The plants would be used as simple bioindicators of the quality of environment [68-73]. However it is absolutely necessary to understand some physiological processes that are connected with the plant response on stress. The data obtained are, despite of this fact, very encouraging to perform deeper research in this area.

\section{Acknowledgements}

We gratefully acknowledge the Grant Agency of the Czech Republic (grant No. GA CR 526/07/0674) for financial support to this work.

\section{References}

1. Galvez, F.; Hogstrand, C.; McGeer, J.C.; Wood, C.M. The physiological effects of a biologically incorporated silver diet on rainbow trout (Oncorhynchus mykiss). Aquat. Toxicol. 2001, 55, 95112.

2. Davis, A.; Drexler, J.W.; Ruby, M.V.; Nicholson, A. Micromineralogy of Mine Wastes in Relation to Lead Bioavailability, Butte, Montana. Environ. Sci. Technol. 1993, 27, 1415-1425.

3. Hogstrand, C.; Wood, C.M. Toward a better understanding of the bioavailability, physiology and toxicity of silver in fish: Implications for water quality criteria. Environ. Toxicol. Chem. 1998, 17, 547-561.

4. Mann, R.M.; Ernste, M.J.; Bell, R.A.; Kramer, J.R.; Wood, C.M. Evaluation of the protective effects of reactive sulfide on the acute toxicity of silver to rainbow trout (Oncorhynchus mykiss). Environ. Toxicol. Chem. 2004, 23, 1204-1210.

5. Hogstrand, C.; Wood, C.M. Toward a better understanding of the bioavailability, physiology and toxicity of silver in fish: Implications for water quality criteria. Environ. Toxicol. Chem. 1998, 17, 547-561.

6. Gorsuch, J.W.; Klaine, S.J. Toxicity and fate of silver in the environment. Environ. Toxicol. Chem. 1998, 17, 537-538.

7. Song, Y.M.; Lu, X.L.; Yang, M.L.; Zheng, X.R. Study on the interaction of platinum(IV), gold(III) and silver(I) ions with DNA. Transit. Met. Chem. 2005, 30, 499-502.

8. Hossain, Z.; Huq, F. Studies on the interaction between Ag+ and DNA. J. Inorg. Biochem. 2002, 91, 398-404.

9. Clemens, S. Toxic metal accumulation, responses to exposure and mechanisms of tolerance in plants. Biochimie 2006, 88, 1707-1719. 
10. Zenk, M.H. Heavy metal detoxification in higher plants - A review. Gene 1996, 179, 21-30.

11. Hamer, D.H. Metallothionein. Annu. Rev. Biochem. 1986, 55, 913-951.

12. Giordani, T.; Natali, L.; Maserti, B.E.; Taddei, S.; Cavallini, A. Characterization and expression of DNA sequences encoding putative type-II metallothioneins in the seagrass Posidonia oceanica. Plant Physiol. 2000, 123, 1571-1581.

13. Sochova, I.; Hofman, J.; Holoubek, I. Using nematodes in soil ecotoxicology. Environ. Int. 2006, 32, 374-383.

14. Fichez, R.; Adjeroud, M.; Bozec, Y.M.; Breau, L.; Chancerelle, Y.; Chevillon, C.; Douillet, P.; Fernandez, J.M.; Frouin, P.; Kulbicki, M.; Moreton, B.; Ouillon, S.; Payri, C.; Perez, T.; Sasal, P.; Thebault, J. A review of selected indicators of particle, nutrient and metal inputs in coral reef lagoon systems. Aquat. Living Resour. 2005, 18, 125-147.

15. Bebianno, M.J.; Geret, F.; Hoarau, P.; Serafim, M.A.; Coelho, M.R.; Gnassia-Barelli, M.; Romeo, M. Biomarkers in Ruditapes decussatus: a potential bioindicator species. Biomarkers 2004, 9 , 305-330.

16. Conti, M.E.; Cecchetti, G. Biological monitoring: lichens as bioindicators of air pollution assessment - a review. Environ. Pollut. 2001, 114, 471-492.

17. McGeoch, M.A. The selection, testing and application of terrestrial insects as bioindicators. Biol. Rev. Cambridge Philosophic. Soc. 1998, 73, 181-201.

18. Leyval, C.; Turnau, K.; Haselwandter, K. Effect of heavy metal pollution on mycorrhizal colonization and function: physiological, ecological and applied aspects. Mycorrhiza 1997, 7, 139153.

19. Petrlova, J.; Krizkova, S.; Zitka, O.; Hubalek, J.; Prusa, R.; Adam, V.; Wang, J.; Beklova, M.; Sures, B.; Kizek, R. Utilizing a chronopotentiometric sensor technique for metallothionein determination in fish tissues and their host parasites. Sens. Actuator B-Chem. 2007, 127, 112-119.

20. Lessire, F.; Delaunois, A.; Gustin, P.; Ansay, M. Biomarkers and bioindicators in vertebrates: importance in evaluation of quality of an ecosystem. Ann. Med. Vet. 1997, 141, 281-290.

21. Kafka, Z.; Puncocharova, J. Bioindicators in the environment monitoring. Chem. Listy 2000, 94, 909-912.

22. Wyrobek, A.J.; Schmid, T.E.; Marchetti, F. Cross-species sperm-FISH assays for chemical testing and assessing paternal risk for chromosomally abnormal pregnancies. Environ. Mol. Mutagen. 2005, 45, 271-283.

23. Sures, B. Environmental parasitology: relevancy of parasites in monitoring environmental pollution. Trends Parasitol. 2004, 20, 170-177.

24. Purcell, T.W.; Peters, J.J. Sources of silver in the environment. Environ. Toxicol. Chem. 1998, 17, 539-546.

25. Purcell, T.W.; Peters, J.J. Historical impacts of environmental regulation of silver. Environ. Toxicol. Chem. 1999, 18, 3-8.

26. Saeki, S.; Kubota, M.; Asami, T. Determination of silver in plants by flame atomic absorption spectrometry. Int. J. Environ. Anal. Chem. 1996, 64, 179-183.

27. Shamspur, T.; Mashhadizadeh, M.H.; Sheikhshoaie, I. Flame atomic absorption spectrometric determination of silver ion after preconcentration on octadecyl silica membrane disk modified with bis[5-((4-nitrophenyl)azosalicylaldehyde)] as a new Schiff base ligand. J. Anal. At. Spectrom. 2003, 18, 1407-1410. 
28. Raoof, J.B.; Ojani, R.; Kiani, A. Kinetic determination of silver ion by its perturbation on Belousov-Zhabotinskii oscillating chemical reaction using potentiometric method. Anal. Sci. 2004, 20, 883-886.

29. Safavi, A.; Iranpoor, N.; Saghir, N. Directly silica bonded analytical reagents: synthesis of 2mercaptobenzothiazole-silica gel and its application as a new sorbent for preconcentration and determination of silver ion using solid-phase extraction method. Sep. Purif. Technol. 2004, 40, 303-308.

30. Schildkraut, D.E.; Dao, P.T.; Twist, J.P.; Davis, A.T.; Robillard, K.A. Determination of silver ions at sub microgram-per-liter levels using anodic square-wave stripping voltammetry. Environ. Toxicol. Chem. 1998, 17, 642-649.

31. Zhang, S.B.; Zhang, X.J.; Lin, X.Q. An ethylenediaminetetraacetic acid modified carbon paste electrode for the determination of silver ion. Chin. J. Anal. Chem. 2002, 30, 745-747.

32. Guo, S.X.; Khoo, S.B. Highly selective and sensitive determination of silver(I) at a poly(8mercaptoquinoline) film modified glassy carbon electrode. Electroanalysis 1999, 11, 891-898.

33. Ye, X.Z.; Yang, Q.H.; Wang, Y.; Li, N.Q. Electrochemical behaviour of gold, silver, platinum and palladium on the glassy carbon electrode modified by chitosan and its application. Talanta 1998, 47, 1099-1106.

34. Wang, J.; Lu, J.M.; Farias, P.A.M. Remote electrochemical monitoring of trace silver. Anal. Chim. Acta 1996, 318, 151-157.

35. Mikelova, R.; Baloun, J.; Petrlova, J.; Adam, V.; Havel, L.; Petrek, J.; Horna, A.; Kizek, R. Electrochemical determination of Ag-ions in environment waters and their action on plant embryos. Bioelectrochemistry 2007, 70, 508-518.

36. Stejskal, K.; Krizkova, S.; Adam, V.; Sures, B.; Trnkova, L.; Zehnalek, J.; Hubalek, J.; Beklova, M.; Hanustiak, P.; Svobodova, Z.; Horna, A.; Kizek, R. Bio-assessing of environmental pollution via monitoring of metallothionein level using electrochemical detection. IEEE Sens. J. 2007, in press.

37. Svancara, I.; Ogorevc, B.; Hocevar, S.B.; Vytras, K. Perspectives of carbon paste electrodes in stripping potentiometry. Anal. Sci. 2002, 18, 301-305.

38. Svancara, I.; Ogorevc, B.; Novic, M.; Vytras, K. Simple and rapid determination of iodide in table salt by stripping potentiometry at a carbon-paste electrode. Anal. Bioanal. Chem. 2002, 372, 795800 .

39. Barek, J.; Muck, A.; Wang, J.; Zima, J. Study of voltammetric determination of carcinogenic 1nitropyrene and 1-aminopyrene using a glassy carbon paste electrode. Sensors 2004, 4, 47-57.

40. Svancara, I.; Kalcher, K.; Diewald, W.; Vytras, K. Voltammetric determination of silver at ultratrace levels using a carbon paste electrode with improved surface characteristics. Electroanalysis 1996, 8, 336-342.

41. Svancara, I.; Vytras, K.; Barek, J.; Zima, J. Carbon paste electrodes in modern electroanalysis. Crit. Rev. Anal. Chem. 2001, 31, 311-345.

42. Lawrence, N.S.; Deo, R.P.; Wang, J. Biocatalytic carbon paste sensors based on a mediator pasting liquid. Anal. Chem. 2004, 76, 3735-3739.

43. Blaedel, W.J.; Wang, J. Mixed Immobilized Enzyme-Porous Electrode Reactor. Anal. Chem. 1980, 52, 1426-1429.

44. Kizek, R.; Vacek, J.; Trnkova, L.; Klejdus, B.; Kuban, V. Electrochemical biosensors in agricultural and environmental analysis. Chem. Listy 2003, 97, 1003-1006. 
45. Masarik, M.; Kizek, R.; Kramer, K.J.; Billova, S.; Brazdova, M.; Vacek, J.; Bailey, M.; Jelen, F.; Howard, J.A. Application of avidin-biotin technology and adsorptive transfer stripping squarewave voltammetry for detection of DNA hybridization and avidin in transgenic avidin maize. Anal. Chem. 2003, 75, 2663-2669.

46. Petrlova, J.; Masarik, M.; Potesil, D.; Adam, V.; Trnkova, L.; Kizek, R. Zeptomole detection of streptavidin using carbon paste electrode and square wave voltammetry. Electroanalysis 2007, 19, 1177-1182.

47. Berry, W.J.; Cantwell, M.G.; Edwards, P.A.; Serbst, J.R.; Hansen, D.J. Predicting toxicity of sediments spiked with silver. Environ. Toxicol. Chem. 1999, 18, 40-48.

48. Bury, N.R.; McGeer, J.C.; Wood, C.M. Effects of altering freshwater chemistry on physiological responses of rainbow trout to silver exposure. Environ. Toxicol. Chem. 1999, 18, 49-55.

49. Bury, N.R.; Galvez, F.; Wood, C.M. Effects of chloride, calcium, and dissolved organic carbon on silver toxicity: Comparison between rainbow trout and fathead minnows. Environ. Toxicol. Chem. 1999, 18, 56-62.

50. Bianchini, A.; Wood, C.M. Mechanism of acute silver toxicity in Daphnia magna. Environ. Toxicol. Chem. 2003, 22, 1361-1367.

51. Bianchini, A.; Bowles, K.C.; Brauner, C.J.; Gorsuch, J.W.; Kramer, J.R.; Wood, C.M. Evaluation of the effect of reactive sulfide on the acute toxicity of silver (I) to Daphnia magna. part 2: Toxicity results. Environ. Toxicol. Chem. 2002, 21, 1294-1300.

52. Bianchini, A.; Grosell, M.; Gregory, S.M.; Wood, C.M. Acute silver toxicity in aquatic animals is a function of sodium uptake rate. Environ. Sci. Technol. 2002, 36, 1763-1766.

53. Call, D.J.; Polkinghorne, C.N.; Markee, T.P.; Brooke, L.T.; Geiger, D.L.; Gorsuch, J.W.; Robillard, K.A. Silver toxicity to Chironomus tentans in two freshwater sediments. Environ. Toxicol. Chem. 1999, 18, 30-39.

54. Karen, D.J.; Ownby, D.R.; Forsythe, B.L.; Bills, T.P.; La Point, T.W.; Cobb, G.B.; Klaine, S.J. Influence of water quality on silver toxicity to rainbow trout (Oncorhynchus mykiss), fathead minnows (Pimephales promelas), and water fleas (Daphnia magna). Environ. Toxicol. Chem. 1999, 18, 63-70.

55. Morgan, T.P.; Wood, C.M. A relationship between gill silver accumulation and acute silver toxicity in the freshwater rainbow trout: Support for the acute silver biotic ligand model. Environ. Toxicol. Chem. 2004, 23, 1261-1267.

56. Ratte, H.T. Bioaccumulation and toxicity of silver compounds: A review. Environ. Toxicol. Chem. 1999, 18, 89-108.

57. Miziolek, A.W.; Palleschi, V.; Schecher, I. Laser-Induced Breakdown Spectroscopy (LIBS), Cambridge University Press, 2006;

58. Buckley, S.G. LIBS comes on strong. Laser Focus World 2006, 42, 95-98.

59. Radziemski, L.J.; Loree, T.R.; Cremers, D.A.; Hoffman, N.M. Time-Resolved Laser-Induced Breakdown Spectrometry of Aerosols. Anal. Chem. 1983, 55, 1246-1252.

60. Cremers, D.A.; Radziemski, L.J. Detection of Chlorine and Fluorine in Air by Laser-Induced Breakdown Spectrometry. Anal. Chem. 1983, 55, 1252-1256.

61. Martin, M.Z.; Wullschleger, S.D.; Garten, C.T.; Palumbo, A.V.; Smith, J.G. Elemental analysis of environmental and biological samples using laser-induced breakdown spectroscopy and pulsed Raman spectroscopy. J. Dispersion Sci. Technol. 2004, 25, 687-694. 
62. Samek, O.; Lambert, J.; Hergenroder, R.; Liska, M.; Kaiser, J.; Novotny, K.; Kukhlevsky, S. Femtosecond laser spectrochemical analysis of plant samples. Laser Phys. Lett. 2006, 3, 21-25.

63. Kaiser, J.; Samek, O.; Reale, L.; Liska, M.; Malina, R.; Ritucci, A.; Poma, A.; Tucci, A.; Flora, F.; Lai, A.; Mancini, L.; Tromba, G.; Zanini, F.; Faenov, A.; Pikuz, T.; Cinque, G. Monitoring of the heavy-metal hyperaccumulation in vegetal tissues by X-ray radiography and by femto-second laser induced breakdown spectroscopy. Microsc. Res. Tech. 2007, 70, 147-153.

64. Limpert, E.; Stahel, W.A.; Abbt, M. Log-normal distributions across the sciences: Keys and clues. Bioscience 2001, 51, 341-352.

65. Hubalek, J.; Hradecky, J.; Adam, V.; Krystofova, O.; Huska, D.; Masarik, M.; Trnkova, L.; Horna, A.; Klosova, K.; Adamek, M.; Zehnalek, J.; Kizek, R. Spectrometric and voltammetric analysis of urease - Nickel nanoelectrode as an electrochemical sensor. Sensors 2007, 7, 1238-1255.

66. Xu, Z.; Chen, X.; Qu, X.H.; Jia, J.B.; Dong, S.J. Single-wall carbon nanotube-based voltammetric sensor and biosensor. Biosens. Bioelectron. 2004, 20, 579-584.

67. Witte, C.P.; Medina-Escobar, N. In-gel detection of urease with nitroblue tetrazolium and quantification of the enzyme from different crop plants using the indophenol reaction. Anal. Biochem. 2001, 290, 102-107.

68. Petrek, J.; Vitecek, J.; Vlasinova, H.; Kizek, R.; Kramer, K.J.; Adam, V.; Klejdus, B.; Havel, L. Application of computer imaging, stripping voltammetry and mass spectrometry for study of the effect of lead (Pb-EDTA) on growth and viability of early somatic embryos of Norway spruce (Picea abies /L./ Karst.). Anal. Bioanal. Chem. 2005, 383, 576-586.

69. Supalkova, V.; Beklova, M.; Baloun, J.; Singer, C.; Sures, B.; Adam, V.; Huska, D.; Pikula, J.; Rauscherova, L.; Havel, L.; Zehnalek, J.; Kizek, R. Affecting of aquatic vascular plant Lemna minor by cisplatin revealed by voltammetry. Bioelectrochemistry 2007, in press.

70. Supalkova, V.; Huska, D.; Diopan, V.; Hanustiak, P.; Zitka, O.; Stejskal, K.; Baloun, J.; Pikula, J.; Havel, L.; Zehnalek, J.; Adam, V.; Trnkova, L.; Beklova, M.; Kizek, R. Electroanalysis of plant thiols. Sensors 2007, 7, 932-959.

71. Supalkova, V.; Petrek, J.; Baloun, J.; Adam, V.; Bartusek, K.; Trnkova, L.; Beklova, M.; Diopan, V.; Havel, L.; Kizek, R. Multi-instrumental investigation of affecting of early somatic embryos of Spruce by cadmium(II) and lead(II) ions. Sensors 2007, 7, 743-759.

72. Vitecek, J.; Adam, V.; Petrek, J.; Vacek, J.; Kizek, R.; Havel, L. Esterases as a marker for the growth of BY-2 tobacco cells and early somatic embryos of the norway spruce. Plant. Cell. Tiss. Org. 2004, 79, 195-201.

73. Zitka, O.; Stejskal, K.; Kleckerova, A.; Adam, V.; Beklova, M.; Horna, A.; Havel, L.; Kizek, R. Utilizing of electrochemical techniques for detection of biological samples. Chem. Listy 2007, 101, 225-231.

(C) 2008 by MDPI (http://www.mdpi.org). Reproduction is permitted for noncommercial purposes. 